\title{
REPORTS
}

\section{Practical Methods of Folklore and Ethnographic Research in Ukraine}

\author{
Maryna Hrymych \\ Kyiv Taras Shevchenko University \\ Kyiv, Ukraine
}

Ukraine is a country with well-developed ethnographic traditions. Sometimes it appears that Ukrainian traditional culture is well preserved because of its active ethnographers, professional and non-professional. It may also be said that ethnographers flourished in Ukraine because they had a rich traditional culture to work with. This makes Ukraine an excellent model for ethnographic and folklore fieldwork methods. This paper is based primarily on the fieldwork experience of the Department of Ethnology and the Study of Local Lore at Kyiv Taras Shevchenko University.

It is important to define terminology and to provide some background information. Ukrainian scholarship, like scholarship in the rest of the Post-Soviet world, makes a distinction between theoretical methodology and practical methodology. The two main practical methods (прикладні методи) are: a) methods of collecting information, primarily fieldwork and the so-called "armchair method," and b) methods of classifying and compiling information, namely cataloguing, tabulating, building databases, creating charts, mapping, and so forth.

Scholars of the post-Soviet era use two terms: методика and методологія. These two words correspond to what, in North America, is termed research, methodology, analysis, theory, approach, and they can even apply to research tools, and information management. The term методологія has two meanings. The first applies to a set of theoretical or analytical methods. The second meaning of методологія corresponds to the terms approach and theory.

A. Methods of collecting information

\section{A.1. Fieldwork}

Fieldwork, in the minds of both scholars and the general public alike, refers to all aspects of observing and collecting ethnographic data. These include interviewing (опитування), observation (спостере- 
ження) and experimentation or the induced natural context method (експеримент).

\section{A.1.1. The interview}

Interviewing can be done either by asking questions directly of the interviewee (безпосереднс опитування) or by using a questionnaire (анкетування). One way of labeling these two types of interviewing is to call them oral and written, respectively.

\section{A.1.1.1.The questionnaire (анкетування)}

Collecting ethnographic and cultural information by using questionnaires is a very old and trusted method. We can trace its origins to Katherine the Great and to the eighteenth century. Upon taking power, Katherine realized that she had no idea how different peoples in her country lived. She felt that she did not understand her country or its cultural diversity. Furthermore, she believed that she could not govern her own state without this knowledge. This prompted her to issue a decree ordering her advisors to compose questionnaires and to collect specific information of interest to her. Scholars and other pedagogical staff participated in carrying out this project throughout the different regions of her domain. A network of interviewees or respondents was created for information gathering. These respondents were mainly the secretaries of village communities (писарi), priests, teachers, even military personnel. The result of this effort was the so called topographical description (топографические описания) of the Chernihiv, Kharkiv and Kherson regions.(1) The descriptions of these regions contain important ethnographic data from the eighteenth century and continue to be a major resource to this day. They allow contemporary researchers to understand a piece of history and a part of culture that would otherwise be inaccessible, and they offer a level of knowledge that is truly exceptional.

Another good example of the effective use of questionnaires dates to almost two centuries later, specifically to the early years of the Soviet state. The All-Ukrainian Academy of Sciences (BYAH) initiated what they called the Ethnographic Commission. Several members of the "Етнографічна Комісія ВУАН" wrote questionnaires on various topics and mailed them to almost every village and district (округа). Thousands of people responded to this Soviet government initiative. As a result, the responses yield a unique ethnographic perspective.(2) They provide 
information about archaic cultural customs, beliefs, and rituals that were still practiced at the beginning of the twentieth century.

Today, the questionnaire method of fieldwork is used for collecting information at the initial stages of research. Such information can then be easily classified by statistical or quantitative methods. This is sufficient for defining the geographical and cultural boundaries of customs or beliefs. For example, data obtained from questionnaires show that the winter solstice mumming ritual called "Koza" is widespread in the northern region of Ukraine. In the Southern part of Ukraine, from Podillia to Odeshchyna, the winter solstice is typically marked by the Malanka rite.(3) Both the Malanka and Koza rituals do not exist at all in the western regions of Ukraine, namely Halychyna (Opillia) and Boikivshchyna. These regions have a well developed tradition of "Vertep" (puppet theatre) and "Shopka" performances. Questionnaires allow us to draw the borders of these cultural traditions on the map of Ukraine. Since we are not able to visit all villages and regions for indepth investigation of cultural traditions, we must rely on constructing questionnaires and on sending them to as many villages on both sides of the ethnographic zone as possible to get the most accurate available perspective on Ukrainian culture. After this is accomplished, we are able to focus on the specific regions that should be targeted for an expedition.

\section{A.1.1.2.Interviewing}

Interviewing can be done either individually, by one person (експедиційне відрядження) or by a group of researchers (експедиція). Expedition here is used to mean the initial first-hand exploration of a subject. There are academic or scientific (науковi) expeditions and also educational or student (навчальні, студентські) expeditions. The structure of the expedition depends on the goals or objectives being pursued. The in-depth exploration of a single region, for example the Chornobyl' zone, differs from studying a single specific topic, such as children's subculture, in several districts. In the first case, when we need to produce a regional survey, specialists in different fields of ethnography explore their own special topic in the given geographical area. In this situation, each interviewer has his or her own questionnaire. In the second case, when we need information about a specific topic from different parts of Ukraine, each fieldworker works with the same questionnaire. This produces more accurate and more consistent data.

Ethnographic workers study interview procedures before they go out into the field. Very good reference materials on ethnographic 
research are available (4) and they present many cases that show how interviews can be handled correctly or incorrectly. Theoretically we know how to interview successfully, and barriers to completing a project are not discussed here. What has been covered and will be presented here are the main problems in doing recorded interviews. Wasting time during an interview is a major issue. If we ask ourselves: "What is the most expensive part of an expedition?", the answer, without a doubt, is time. Wasting time during an interview could be construed as an ethnographic "crime" because we sacrifice a valuable opportunity that could be used for gathering information. But students are not guilty when something as precious as time is lost; the fault lies with the instructors.

Attention to detail in the questionnaire is crucial. Questionnaires can be long, but this does not mean that each and every possible question needs to be included. At the same time, it is good to make sure that each student has a stock of questions for special situations, such as when he or she is lucky enough to meet the extraordinary interviewee. Let us imagine a situation when a student-interviewer comes across a special opportunity to interview a respondent on a specific topic and that he does not have a questionnaire properly tailored to that topic. For example, let us say that the student encounters an old man who is a leading authority on local sacred places in the folk culture of Crimean Tatars. What happens if the interviewer has not prepared for this opportunity and does not have the appropriate questionnaire? What is he to do? One solution is for the student to implement a method referred to as empathy, a technique described by K.Malinowski. The student-interviewer should then imagine him or herself in a specific ritual or non-ritual situation or context. Simple or primary questions like: why, what, or when can prove very effective. Another technique that helps keep the dialogue flowing is to turn the interview into a conversation and to contribute comments. Phrases that can help this flow of ideas are: "sorry, I didn't catch what you meant," "could you please repeat that," "could you please spell that," "could you please show me how it's done," "let me try it," "let's try it together," "please take me to this place," and so on. All questions and requests of this type are very helpful and can enrich the information provided in an interview.

Sometimes students are the only recorders of an interview. With this possibility in mind, students must learn how to lead the conversation. The model of cooperation between interviewer and interviewee should be like the model of the proverbial Ukrainian family. In the proverb, it is said that the husband believes that he is the head of the family. In 
reality, it is the woman who is the real decision-maker. Metaphorically, the man is the head and the woman is the neck; where the neck turns, the head follows. The same should be true in ethnographic interviews: the interviewer should be the neck that turns and leads while, at the same time, the interviewee should be convinced that he or she is the leader or the head of the conversation. This approach is essential because much, if not most, of the information gathered is not made public but placed in what we call memory storages or archives. In addition, good story-tellers or talented narrators are not always good informants or interviewees. We, as researchers, have to control them. That is why we need to know little secrets or subtle tricks so that we can interrupt without embarrassing the interviewee. This subtle art must be taught to students. The simplest way to interrupt an interviewee is to compliment him or her or to express amazement, to produce the "wow" moment. And while the interviewee enjoys the compliment, the researcher can gently put them back on the right track. Of course care must be exercised and all fieldwork must be ethical. Establishing and maintaining good fieldwork relations and not embarrassing the person being interviewed is essential. A delicate balance between good relations and the imperative to extract information must be achieved. The objectives of research must not be forgotten. Facilitating the interview is an important consideration. The most effective interviews are those conducted by at least two people. One keeps the personal conversation flowing as the interview is being conducted, extracting the desired information, while the second person takes care of the technical side by taking notes, making records, and running whatever audio or video equipment is being used.

It is a given that all preparations should be handled well in advance of the interview. The researcher should check the sound quality of the recorder. He or she should make sure that the camera lens cap is off. He or she should review the questionnaire and make sure that it is relevant and accurate. Other details should be handled as appropriate. The secondary interviewer should take notes and is considered a key silent partner in the interview. After the interview is complete, a detailed report should be written. It should be noted that in North-America the term "fieldwork methods" includes note taking, field diaries, questionnaires, audio recording, video recording, and photography. In Ukrainian scholarly tradition these are considered research tools which help in collecting the information. 


\section{A.1.2. Observation}

The next method that should be focused on is observation. I recommend it to my students when an interview does not seem safe. An example of this is collecting information from beggars or homeless people and other marginal groups. In this case an interviewer has a list of variables that they must pay attention to. For example, what types of clothing are the subjects wearing? What speech formulas do they use? What is their "business success," in other words, how successful are they at gathering alms? Does the beggar under observation have his own place or not? Does he have a bodyguard and so on? Observation as a technique is helpful in the ritual context of weddings, funerals and the baptism of a child.

\section{A.1.3. Experiment}

This method usually is not used in Ukrainian ethnographic research practice.

\section{A.2. Armchair methods}

When the opportunity to conduct fieldwork does not exist because of time constraints, or the distance to the desire site, or because of personality and psychological reasons, we can use the armchair method of collecting the information. This approach includes research in archives, museums, libraries, private collections, and so on. Research based on existing collections can be very effective and is popular in contemporary Ukrainian scholarship because Ukraine has an enormous quantity of archive materials which have still not been examined and otherwise researched.

\section{B. Methods of classifying information}

After fieldwork is complete, it is time to compile and classify the collected information (систематизація, упорядкування, класифікація). The main methods of classification are: transcribing, cataloguing, building databases, composing tables, drawing charts, and making maps. In many senses the process of classification begins before data is even recorded and a well-constructed questionnaire is the first step to subsequent successful classifying. 


\section{B.1. Composing the questionnaire}

The principles of composing questionnaires are as follows. The questionnaire should be built as a hierarchical system. Questions are arranged in categories. The main question is put on the head of the category. If the respondent does not know the answer to this question, then the interviewer proceeds to the next category. If the respondent does remember something, then the researcher proceeds to ask all the questions from that category. For example, a questionnaire about weddings is divided into multiple categories. One such category would be "гільце" or wedding tree. The first question would typically be: "At weddings in your area, did you have the гільце, вільце, деревце, квітка, йолка, etc." If the answer is "no," then the researcher proceeds to the next category. If the answer is "yes," then the student is supposed to have a set of questions that might be typified by the following: what is the local term for this item? When it is prepared and by whom? What are the materials that are used and why? Who cuts the tree and who decorates the tree? Does an older age group (beyond marriageable age) participate in this custom? What is done with the wedding tree on Saturday, on Sunday? What is done with it after the wedding? How long is it kept and where and so on?

\section{B.2. Transcription}

Transcription in Ukraine is done by the interviewer or his assistant. It is important to verify the data file of the interview (паспортичка) which contains information about the informant, the time and place of the interview, the definition of the main topic, and the key words of the interview or survey. Transcription principles were established in Soviet times and are still effective.

\section{B.3. Cataloguing and storing the information}

All activities involved in storing and retrieving information fall under the North-American rubric of information management. In Ukraine we feel that archive and museum workers are not only information managers, but also active co-workers in the process of classifying, compiling, and describing the data collected through fieldwork. Thus, they are our partners in research. They do the archiving, ethnographic and audio-visual archiving, and they produce museum exhibits. It may also be informative to arrange the information into tables, charts, and diagrams. 


\section{B.4. Description of the information}

The last step is for the researcher to describe his or her information, to write the report, survey, commentary, and so forth (опис, передмова, післямова, наукові примітки, покажчики, коментарі). The term науковий апарат is sometimes used in Ukrainian scholarship to refer to this activity. Practical methods, therefore, are the primary research tools which help folklorists and ethnographers collect their data and prepare it, through classification, for further study. The next step of research is the theoretical one. This involves analysis based on different theories and approaches.

\section{NOTES}

1 Shafonskii, A. 1786. Шафонский А. Черниговского наместничества топографи-ческое описание [Tороgraphic Description of the Chernihiv Region]; Атлас Харьковского наместничества 1787 г. с топографическим описаним [Atlas of the Khar'kiv Region of 1787, with a Topographic Description]. Kharkiv, 1902; Карта Херсонской губернии [A Map of the Kherson Province]. St. Petersburg, 1880; Pokhylevych, L., ed. 1887. Уезды Киевский и Радомысльский: Стат. и ист. заметки о всех насел. местностях в этих уездах и с подроб. картами их [The Kyiv and Radomysl' Provinces: Statistical and Historical Notes on All the Inhabited Locales in these Provinces along with Detailed Maps]. Київ.

2 See: Hurii, O. I. and Parakhina, M. B. 2004. Гурій O.I., Парахіна М.Б. Етнологічні осередки України в 20-х - на початку 30$x$ рр.. ХХ ст. Нарис діяльності [Ethnographic Societies of Ukraine in the 20 s - Beginning of the 30s of the XX century. Description of their Activities]. Київ.

3 See: Kurochkin, O. 1995. Курочкін О. Українські новорічні обряди "Коза" $i$ "Маланка" [Ukrainian New Year Rituals "Goat" and "Malanka"]. Опішнє.

4 See recent publications on this topic: Iuriichuk, M.I. and Kostyk, V. V. 1997. Юрійчук М.I., Костик В.В. Фольклорна практика: Методичний збірник [Folklore Practice: A Methodological Collection]. Чернівці; Kravchenko, А. I. 2003. Кравченко А.И. Социальная антропология [Social Anthropology]. Москва; Ivanyts'kyi, A. I. 1997. Іваницький A.I. Українська музична фольклористика [Ukrainian Musical Folkloristics]. Kyiv; Skotnykova, T. V. and Rizun, V. V. 2006. Скотникова Т.В., Різун В.В. Методи наукових досліджень у 
журналістикознавстві: Навчальний посібник [Research Methods in Journalism: A Textbook]. Київ. 